\title{
Analysis of the influence of "business tax to VAT" on financial management of enterprises
}

\author{
Cheng Yan ${ }^{1,}$, , Liu Qun ${ }^{2, b}$ * \\ 1,2 Guangzhou Vocational College of Science and Technology, Guangzhou, 510550, China \\ aemail: 305935207@qq.com, bemail: 425553879@qq.com \\ * the corresponding author
}

Keywords: Business tax to VAT, Financial management of enterprises, Influence

\begin{abstract}
As an important measure of China's tax system, the "business tax to VAT" plays an important role in reducing the overall tax revenue and enhancing the vitality of enterprises. It can provide strong support for the development of enterprises to explore actively the impact of "business tax to VAT" on the financial management of enterprises, and to optimize constantly the financial management mode of enterprises. At the same time, the "business tax to VAT" is the breakthrough point in our China's economic transformation. From the pilot stage to the extension stage, the key step of the tax reform in China has been finished,it is now the main development direction of the reform process of our tax system and VAT. The influence of "business tax to VAT" on the financial management of enterprises is analyzed, and specific management measures are put forward.
\end{abstract}

\section{Introduction}

The implementation of the "business tax to VAT" policy is not only a new tax policy issued by the party and the state according to the current economic and political situation in China, but also plays an important role in the economic restructuring of our country. It lays a solid foundation for the sustainable development of our economy and avoids Enterprises' repeated tax relief to reduce the maximum extent of tax burdens to promote the long-term development of enterprises. At the same time, with the implementation of the "business tax to VAT", the new work requirements and standards for the enterprise financial management are presented to promote enterprises to adapt to the policy of "business tax to VAT", to continue to explore better financial management mode, and to optimize constantly the enterprise financial management process. Among them, the "business tax to VAT" is what the business tax is changed to the value-added tax (VAT), which refers to the economic policy of changing the traditional business tax items into the category of VAT, and since 2011 , the country has promulgated the pilot program to increase the pilot program, and the range of the 16 years has been extended to all parts of the country. In view of this, it is of great significance to study the impact of "business tax to VAT" on the financial management of enterprises.

\section{The influence of "business tax to VAT" on the financial management of enterprises}

Since the promulgation of pilot scheme of the "business tax to VAT", it has been deeply concerned by all sectors of society and extended to all parts of the country until 2016 . The statistics show that more than 12 million enterprises have been actively involved in the process of tax reform since the pilot project has been carried out. With the improvement of the system and the increasing regulations, the number of enterprises involved in the future will increase continuously, which means that the reform of tax system and VAT will be the main direction of the reform of tax system in China. With the deepening of the operation and promotion process of "business tax to VAT", the impact on enterprise financial management is more comprehensive. How to do a good job in the management of enterprises' financial management is a major problem faced by managers in the actual work process. From a substantive point of view, the change of business tax is a process of tax change, and the traditional business tax payment project is changed to a VAT payment project. 
The VAT is mainly responsible for the value-added part of the service or product, to a certain extent, it reduces the duplication tax link. And the "business tax to VAT" can run in the modern service industry and transportation industry, and it can be extended to all walks of life. From the actual situation of the pilot, the change of the tax policy has a great impact on small scale enterprises, for example, the business tax rate of small scale advertising enterprises is not higher than $5 \%$ before the implementation of the new policy, and the tax rate after the implementation is $3 \%$. From this, we can see that the new tax policy has obvious impact on tax reduction for small-scale enterprises. With the expansion of the scope of the policy, the number of pilot enterprises is increasing, which is of great significance to the adjustment of the industrial structure and the enhancement of the international competitiveness of goods and services in China. In the service industry, business tax is levied in full, and the tax burden of enterprises will be increased.

After the implementation of the new policy, it is beneficial to develop the tax policy for support to the third industry, which is conducive to the rapid development of the third industry in China, especially the development of the emerging service industry. The export tax rebate can not be carried out under the background of business tax, which will weaken the international market competitiveness of China's goods and services, and to some extent, it will impede the development of export enterprises. After the implementation of the policy, China's tax system will be in line with the international market, and these enterprises will gain a price advantage in international competition to enhance its international competitiveness. At the same time, from the perspective of enterprise finance, the new reform measures of the tax system have a far-reaching impact on the enterprise financial management, covering the tax burden, the accounting and the invoice management. From the perspective of a single tax burden, the policy of "business tax to VAT" is more obvious for the small scale taxpayers and the general value-added tax taxpayers.

Among them, after the implementation of the new tax system, for the small scale taxpayers, these tax rates are adjusted from $5 \%$ business tax rate to $2 \%$ VAT, and the modern service industry that cannot deduct the amount of tax has increased the amount and scope of the deductible import tax, and the amount of tax deductible for the deduction of transportation expenses is increased from 7\% to $11 \%$. From the point of view of the industry, the proportion of fixed assets in the transportation industry is large, and the tax rate increases from $3 \%$ to $11 \%$, and the tax burden change is small, but there is a small tax decline in some enterprises in the actual expropriation, and the decline is obviously different from that before the implementation of the policy. For the industry with non deductible assets and labor services as the main cost source, after the implementation of the reform, the difference of tax burden is obviously less and the tax burden of some enterprises is up to rise. In reform, we should emphasize the interests of such enterprises and adjust the taxable amount of tax rates appropriately.

The change of policy means that the process of tax change directly affects the accounting process. At the same time, because the business tax does not exist such as sales tax and entry tax, and its corresponding cost is listed according to the actual occurrence, so the principle and method of income entry after the new policy will change fundamentally. For example, taking the service industry as an example, after the implementation of the new policy, the income is deducted according to a certain tax rate, and the amount of the tax is confirmed, and the cost should be deducted from the amount of the entry tax. At the same time, the sales tax amount and the entry tax amount are calculated mainly through the subject of tax payment in order to ensure that the tax payable in the current period is equal to the difference between the current sales tax and the entry tax. The tax revenue under the business tax is calculated on the basis of the income and the balance of revenue and expenditure. From this, we can see that the tax accounting, cost accounting and income accounting have changed enormously after the implementation of the new policy.

At the same time, because this policy can not be popularized in the whole country at one time, following the principle of "some areas first pilot, all area re popularizing", it will aggravate the difficulty of accounting work of enterprise cross regional business, which will result in the obvious difference of accounting between the pilot region and the non pilot region. The enterprises cross regional business take the different taxes between the pilot regions and the non pilot regions as the 
breakthrough point to make the policy cohesion and adjustment, which objectively increases the difficulty of the enterprise accounting work. After the implementation of new policy, for the enterprises of diversified economy, its requirements for accounting work will be more stringent, The new policy requires that the enterprises accurately distinguish the nature of various business operations and carefully check the detailed rules of various business operations. Once it is unable to distinguish the business, the tax accounting is carried out according to the highest tax rate.

Because most service enterprises belong to diversified economy, small and medium-sized service enterprises can reduce the burden of tax burden by dividing their business according to taxes. After the implementation of the policy, the types of related invoices will also change. To a certain extent, it will aggravate the difficulty of invoice management. For example, under the original business tax system, the service enterprises only need to open the tax invoice in the service industry. The difference between the tax revenue and the sales tax is large, and the new requirements and standard for the management of the VAT invoice are put forward. According to the difficulty of management, VAT invoice management can be divided into small scale taxpayers and general taxpayers. Small scale taxpayers are applicable to ordinary invoices. The invoice management is basically similar to the state of business tax, while the general taxpayer is applicable to ordinary invoices and special invoices, and the tax department and the scope of use are clearly defined. The possibility of legal risk is caused by incorrect use of invoices.

\section{Practical measures for enterprise financial management under the new policy}

From the perspective of small scale taxpayers, the financial and tax opportunities brought about by the new policy of business tax to VAT are embodied in the national direct tax rate, that is, the original $5 \%$ business tax rate is reduced to 3\% VAT tax rate. But for the general taxpayers, it is necessary to combine the advantages of the tax reform policy to combine the actual situation of each tax subject, and to develop the best tax planning scheme by digging more customer resources, and to realize the opportunity to enhance the market competitiveness of the pilot enterprises from the policy. As the scope of VAT levy involves circulation, the subject of tax payment can transfer through the tax burden in the circulation link to achieve the goal of reducing the new tax. For example, For example, the VAT input tax is deducted from the circulation link, the customer obtains the VAT invoice, which can increase the VAT deduction and reduce the tax cost. It can be seen that under the same quality of service and charging conditions, the general taxpayer will make use of the policy advantage of "business tax to VAT" to win more customers' resources. At the same time, enterprises actively study the specific items in the new policy, it will be conducive for the enterprises to continuously expand customer resources. For example, the new policy clearly stipulates that "the experimental enterprises approved by the people's Bank of China, the Ministry of Commerce and the CBRC can enjoy VAT tax benefits, and the tax payers who operate the leasing business provide VAT over 3\% tangible movable financial leasing services can enjoy the VAT preferential of immediate repayments.".

\section{Conclusions}

Through analysis and exploration, it is recognized that the new tax policy is an opportunity for enterprises to coexist with opportunities and challenges. On the one hand, the new policy can eliminate the abuse of duplication of Taxation and reduce the tax burden of most enterprises, especially small enterprises. Since the standard of raising the value of VAT taxpayers, the majority of small scale tax payers are paying 3\% tax to complete the tax payment, which greatly reduces the tax burden. On the other hand, from the feedback of Shanghai in the first quarter, more than $70 \%$ enterprises have realized the decline in tax burden, but the tax burden of enterprises in the transportation industry has risen obviously, and the workload of tax declaration and VAT special invoice management is increased in a certain extent. 


\section{References:}

[1] Jiang Xichong.The research on the application of comprehensive practical teaching system of Accounting Specialty in Higher Vocational Colleges[J],Science and Technology Innovation Herald,2014(11).

[2] Luo Chunling. The thinking on the teaching of the course of tax practice under the environment of Finance and information [J], China's management information,2015(22).

[3] Ni Ping.related to construction of practical teaching materials of Higher Vocational Accounting Specialty[J], The new curriculum ,2015(Second).

[4] Chen Xiaoan.Improving practical teaching, improve the professional skills of tax [J],Journal of Inner Mongolia Finance and Economics College,2011(3).

[5] Research Group of finance and taxation. A study on the current situation and problems of the basic theory and skills of the students of finance and taxation specialty and Countermeasures[J],Journal of Inner Mongolia Finance and Economics College,2006(4). 